\title{
Endotoxins in surgical instruments of hip arthroplasty
}

\author{
Endotoxinas em instrumentais cirúrgicos de artroplastia do quadril \\ Endotoxinas en instrumentales quirúrgicos de artroplastia de la cadera
}

\begin{abstract}
Vania Regina Goveia ${ }^{1}$, Isabel Yovana Quispe Mendozaํ, Gilberto Lima Guimarães ${ }^{1}$, Flavia Falci Ercole', Bráulio Roberto Gonçalves Marinho Couto², Edna Marilea Meireles Leite ${ }^{3}$, Maria Aparecida Resende Stoianoff ${ }^{4}$, José Antonio Guimarães Ferreira ${ }^{4}$
\end{abstract}

How to cite this article:

Goveia VR, Mendoza IYQ, Guimarães GL, Ercole FF, Couto BRGM, Leite EMM, et al. Endotoxins in surgical instruments of hip arthroplasty. Rev Esc Enferm USP. 2016;50(3):405-410. DOI: http://dx.doi.org/10.1590/S0080-623420160000400005

${ }^{1}$ Universidade Federal de Minas Gerais, Escola de Enfermagem, Belo Horizonte, MG, Brazil.

${ }^{2}$ Centro Universitário de Belo Horizonte, Instituto de Engenharia e Tecnologia, Belo Horizonte, MG, Brazil.

${ }^{3}$ Universidade Federal de Minas Gerais, Hospital Risoleta Tolentino Neves, Belo Horizonte, MG, Brazil.

${ }^{4}$ Universidade Federal de Minas Gerais, Instituto de Ciências Biológicas, Belo Horizonte, MG, Brazil.

\begin{abstract}
Objective: To investigate endotoxins in sterilized surgical instruments used in hip arthroplasties. Method: A descriptive exploratory study conducted in a public teaching hospital. Six types of surgical instruments were selected, namely: acetabulum rasp, femoral rasp, femoral head remover, chisel box, flexible bone reamer and femoral head test. The selection was based on the analysis of the difficulty in removing bone and blood residues during cleaning. The sample was made up of 60 surgical instruments, which were tested for endotoxins in three different stages. The Endosafe ${ }^{\mathrm{TM}}$ Gel-Clot LAL (Limulus Amebocyte Lysate method) was used. Result: There was consistent gel formation with positive analysis in eight instruments, corresponding to $13.3 \%$, being four femoral rasps and four bone reamers. Conclusion: Endotoxins in quantity $\geq 0.125 \mathrm{UE} / \mathrm{mL}$ were detected in $13.3 \%$ of the instruments tested.
\end{abstract}

\section{DESCRIPTORS}

Endotoxins; Surgical Instruments; Arthroplasty, Replacement, Hip; Orthopedic Nursing; Operating Room Nursing.

\section{Corresponding author:}

Vania Regina Goveia

Escola de Enfermagem, Universidade

Federal de Minas Gerais

Av. Prof. Alfredo Balena, 190, EE, sala 204

CEP 30130-100 - Belo Horizonte, MG, Brazil

vaniagoveia@ufmg.br
Received: 12/09/2015

Approved: 04/20/2016 


\section{INTRODUCTION}

Joint replacement surgeries using orthopedic implants bring benefits to patients, such as pain relief and recovery of movements. However, they require long-term follow-up to determine their effectiveness and safety, since they might involve complications ${ }^{(1-2)}$.

There are two flaws associated with orthopedic implants. The first is of mechanical nature, resulting from the excessive use of the prosthesis, its displacement or misalignment, physical stress and bone fracture. The second is of biological nature, caused by inflammation due to the presence of particles where the prosthesis is located. Although infection is one of the causes for the loosening of a prosthesis in about $1.5 \%$ of the patients, a non-infectious complication or aseptic loosening is the main cause of surgical revision ${ }^{(3-5)}$.

In the United States, 500,000 arthroplasties are performed every year; of these, 40,000 undergo through revisions due to aseptic loosening, often associated with the presence of endotoxins. Presence of osteolysis around the prosthesis is observed in aseptic loosening, due to the presence of particles generated from the implant. If endotoxins are present, they adhere to these particles, being probably one more factor to inducing the loosening. Endotoxins are found in the outermost membrane of Gram-negative bacteria and belong to the phospholipids class called lipopolysaccharides (LPS). Their release occurs due to the cell death, but there is evidence that it happens in a lower proportion, during the process of cell growth and division ${ }^{(3-7)}$.

These findings suggest the need to know the endotoxins' role in these situations of inflammatory response, where there are not clinical and microbiological signs of infection. Initially, it might seem contradictory to address aseptic loosening without excluding the presence of a subclinical level of bacteria that may colonize orthopedic implants, form biofilm and be the source of endotoxins ${ }^{(5)}$.

The limit of endotoxins in health devices was regulated by the U.S. Food and Drug Administration (FDA) for manufacturers of medical devices, and it depends on both the intended use and their contact with body surfaces, spaces and fluids. For devices that come into direct or indirect contact with cardiovascular and lymphatic systems, the limit is $0.5 \mathrm{UE} / \mathrm{mL}$ or $20 \mathrm{UE} /$ device. However, regarding devices that come into contact with the cerebrospinal fluid, the limit is $0.06 \mathrm{UE} / \mathrm{mL}$ or $2.15 \mathrm{UE} /$ device. Nonetheless, there are not established or regulated limits for endotoxins in sterilized surgical instruments, or any requirement to conduct tests that evaluate their presence ${ }^{(7-9)}$.

In this respect, the hypothesis that there might be endotoxins in surgical instruments is presented and, therefore, they can contribute to the aseptic loosening of orthopedic implants. Therefore, the objective of this study was to investigate the presence of endotoxins in sterilized surgical instruments used in hip arthroplasties.

\section{METHOD}

A descriptive exploratory study was conducted to investigate endotoxins in sterilized surgical instruments used in hip arthroplasty surgeries.
The study was conducted in a public teaching hospital that provides high complexity care in traumatology, located in the city of Belo Horizonte, in the state of Minas Gerais. This hospital has a surgical center with six operating rooms and a sterile processing department (SPD), where surgical instruments are processed.

Specific sets of surgical instruments for hip arthroplasty contain about 50 pieces (Figure 1). These were analyzed along with the nurse coordinator of the SPD and the orthopedic physician coordinator of hip surgery, with the aim to classify instruments that present difficulty in the removal of bone and blood residues during the cleaning for further sterilization. Six types of surgical instruments were selected, namely: acetabulum rasp, femoral rasp, femoral head remover, chisel box, flexible bone reamer and femoral head test, totaling 29 pieces.

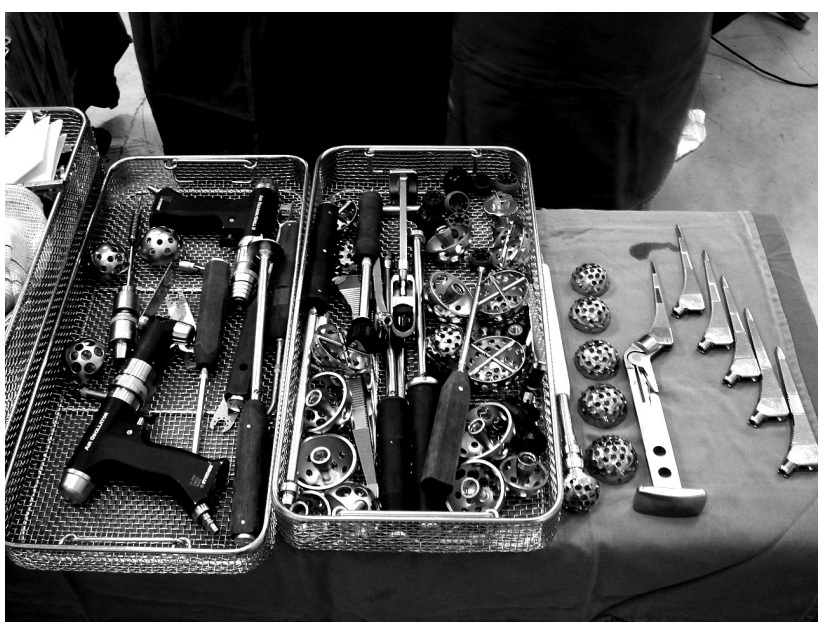

Source: author's file.

Figure 1 - Set of surgical instruments for hip arthroplasty - Belo Horizonte, Minas Gerais, Brazil, 2014.

The instruments' sample size was calculated considering studies with the aim to define if a specific event occurs or not in a given population ${ }^{(10)}$. More specifically, to identify the presence of endotoxins in the selected instruments used in hip arthroplasties. In this situation, the calculation of the sample size (n) follows:

$$
\mathrm{n}=\frac{\log (\beta)}{\log (1-p)}
$$

where: $1-\beta=$ power of the study (usually $\beta=0.05$ or $\beta=0.10$ )

$\mathrm{p}=$ expected proportion of the event's occurrence in the population

In the sample calculation, an expected proportion ( $\mathrm{p}$ ) of at least $10 \%$ of presence of endotoxin in instruments $(p=0.10)$ and a power of $90 \%(\beta=0.10)$ were considered. In this case, the sample size must include at least 22 instruments.

The selected instruments were submitted to the SPD routine processes, namely: cleaning with enzymatic detergent in ultrasonic and manual washers; rinsing in drinking water; packaging in polypropylene blanket and sterilization in saturated steam under pressure. The SPD made the surgical instruments available in three different stages, in which 25,17 and 18 pieces were respectively tested, totaling 60 
instruments. It is important to note that the tests were conducted according to the material provided by the hospital, considering that it was not possible to test the 29 selected pieces initially, in none of the three stages.

In the SPD daily routine, the sterilization processes are monitored by physical, chemical and biological indicators. The unit uses drinking water for the processing of materials, whose standards are evaluated every four months, according to the edict MS No. 2914/2011 ${ }^{(11)}$ of the Brazilian Ministry of Health. The validation of the steam sterilization process in the SPD is conducted every year for sterilization assurance, which includes the qualification of equipment regarding their installation, operation and performance. Laboratorial analyses were conducted in the microbiology department of the Instituto de Ciências Biológicas of the Universidade Federal de Minas Gerais (ICB/UFMG, as per its acronym in Portuguese).

The sterilized surgical instruments ready for use were analyzed with the Endosafe ${ }^{\mathrm{TM}}$ gel-clot LAL method (Limulus Amebocyte Lysate by Charles River Laboratories, Inc. USA) for the detection of endotoxins, according to standards established by the US Pharmacopoeia ${ }^{(12)}$.

Using the aseptic technique in laminar flow cabinet, the instruments were transferred to a sterile container with $200 \mathrm{~mL}$ of water for apyrogenic injection (AI). They were submitted to sonication through the Bransonic 2510R-MT Ultrasonic Cleaner for 30 seconds, at a frequency of $42 \mathrm{KHz}$ and vortex agitation for 15 seconds. After this process, an aliquot of $20 \mathrm{~mL}$ of $\mathrm{AI}$ obtained from the processing of each instrument was transferred to an apyrogenic conical tube, for conducting the endotoxins detection test.

The biological principle of the Endosafe ${ }^{\mathrm{TM}}$ LAL test derives from the blood coagulation observed in the American horseshoe crab Limitus polyphemus, when in contact with lipopolysaccharides (LPS) present in Gram-negative bacteria. The test used presents lambda $(\lambda)$ sensitivity of 0.125 $\mathrm{UE} / \mathrm{mL}$, which corresponds to $0.025 \mathrm{ng} / \mathrm{mL}$.

The Endosafe ${ }^{\mathrm{TM}}$ LAL and the standard endotoxin were reconstituted with AI, according to the manufacturer's guidelines. After the reconstitution of the endotoxin, series of dilutions were conducted to confirm the LAL sensitivity. The test tubes were prepared in duplicate with $100 \mu \mathrm{L}$ of the diluted solutions and for the positive controls, according to the manufacturer's indication. Then, $100 \mu \mathrm{L}$ of LAL reagent were added. The same procedure was conducted for the experiment tubes, being $100 \mu \mathrm{L}$ of the conical tubes transferred to the test tubes in duplicate, and $100 \mu \mathrm{L}$ of LAL reagent were added.

The test tubes were incubated in water-bath for one hour, at the temperature of $37 \pm 1^{\circ} \mathrm{C}$. The reading of each tube was conducted according to the manufacturer's instructions, that is, by direct observation of gel formation, being the result interpreted as positive when the tube is inverted to $180^{\circ}$ and the gel maintains its integrity. The negative result is characterized by the absence of gel or a viscous mass that does not adhere to the bottom of the tube when it is inverted. All glassware used in the experiments was previously depyrogenazed through a method previously validated by the manufacturer.
For statistical analysis, the proportion of contamination from endotoxin was estimated by means of point estimation and by $95 \%$ confidence interval.

The research project was approved by the Research Ethics Committee of the Universidade Federal de Minas Gerais UFMG, under protocol no ETIC 0300.0.203.000-10.

\section{RESULTS}

The surgical instruments submitted to analysis for the detection of endotoxins totaled 60 pieces and are presented in Table 1.

Table 1 - Distribution of complex surgical instruments obtained for test: risk of contamination from endotoxins - Belo Horizonte, Minas Gerais, Brazil, 2014.

\begin{tabular}{|c|c|c|c|c|}
\hline $\begin{array}{l}\text { Type of } \\
\text { instrument }\end{array}$ & $N$ & $\begin{array}{l}\text { END } \\
\geq 0.125 \\
\text { UE } / \mathrm{mL}\end{array}$ & \begin{tabular}{c}
\multicolumn{1}{c}{ Risk of } \\
contamination \\
by endotoxins
\end{tabular} & $\begin{array}{l}95 \% \text { confidence } \\
\text { interval for risk of } \\
\text { endotoxins }\end{array}$ \\
\hline $\begin{array}{l}\text { Acetabulum } \\
\text { rasp }\end{array}$ & 19 & 0 & - & - \\
\hline Femoral rasp & 15 & 4 & $27 \%$ & {$[5 \% ; 49 \%]$} \\
\hline $\begin{array}{l}\text { Femoral head } \\
\text { remover }\end{array}$ & 1 & 0 & - & - \\
\hline Chisel box & 1 & 0 & - & - \\
\hline Initial reamer & 2 & 0 & - & - \\
\hline $\begin{array}{l}\text { Femoral } \\
\text { head test }\end{array}$ & 12 & 0 & - & - \\
\hline $\begin{array}{l}\text { Acetabulum } \\
\text { test }\end{array}$ & 5 & 0 & - & - \\
\hline $\begin{array}{l}\text { Flexible bone } \\
\text { reamer }\end{array}$ & 5 & 4 & $80 \%$ & [28\%; 99\%] \\
\hline Total & 60 & 8 & $13 \%$ & {$[6 \% ; 26 \%]$} \\
\hline
\end{tabular}

In the first stage, the hospital provided 25 sterilized surgical instruments for analysis, namely: eight acetabulum rasps, eight femoral rasps, one femoral head remover, one chisel box, one initial reamer and six femoral head tests. In the second stage, 17 instruments were provided, being eight acetabulum rasps, four femoral rasps and five acetabulum tests. In the third stage, 18 instruments were provided, being three acetabulum rasps, three femoral rasps, one initial reamer, six femoral head tests and five flexible bone reamers.

After tests were conducted in the first stage, consistent gel formation was observed, with positive analysis for endotoxins in four femoral rasps among the 25 surgical instruments. Tests in the second stage did not show consistent gel formation in any of the 17 surgical instruments tested. Tests in the third stage showed consistent gel formation with positive analysis for endotoxins in four flexible bone reamers among the 18 surgical instruments.

The positive analysis represents a quantity of $\geq 0.125 \mathrm{UE} /$ $\mathrm{mL}$ in the solution of the instrument tested. Therefore, for 60 instruments submitted to test for the detection of endotoxins, there was consistent gel formation with positive analysis in eight surgical instruments, corresponding to $13.3 \%$.

\section{DISCUSSION}

The unit that processes surgical instruments in health services should meet minimum quality standards to ensure 
patient safety ${ }^{(13)}$. The conditions for processing surgical instruments practiced in 249 SPDs were investigated by the health department of England, classifying them by a quality standard. The evaluation had the aim to investigate provision and use of equipment, trained human resources, management and technical support to the reprocessing and compliance with good practice and current legislation. Furthermore, the units were evaluated regarding the adoption of special care for the processing of materials used in procedures with a high risk of transmitting the variant of the Creutzfeldt-Jacob disease. The results showed that $44 \%$ of the services were classified with unacceptable standards, and only $17 \%$ were classified with good standards. In this respect, the government developed an action plan, announced investments to improve the SPDs and a new evaluation was conducted ${ }^{(14)}$.

The presence of endotoxins in $80 \%$ of the flexible bone reamers reinforces the technical difficulty in processing this study, reported by professionals who work in SPDs. It is recommended that the solution used for the cleaning of instruments have contact with all their surfaces; furthermore, composite materials must have their parts dismantled, according to the manufacturer's guidelines. In case the cleaning of all surfaces cannot be performed, residues of organic matter may remain, and if they are not removed before sterilization, they may cause harm to patients ${ }^{(15)}$.

In Brazil, SPDs are regulated by the National Health Surveillance Agency (ANVISA, as per its acronym in Portuguese), which established good practice requirements for the processing of health products in 2012. Aspects such as human resources and materials, infrastructure and all processes performed in this area are regulated both for health services and reprocessing companies. Regarding the rinsing water for health products, it must meet drinkability standards; however, the rinsing of critical materials used in surgeries of orthopedic implants must be performed with purified water ${ }^{(16)}$.

The Brazilian Pharmacopeia establishes standards and defines purified water as drinking water that was submitted to any kind of treatment for the removal of potential contaminants, and the treatment process consists of distillation, ion exchange, and reverse osmosis. It must meet purity requirements and be tested regarding its acidity and alkalinity, oxidizable substances, conductivity, total organic carbon, ammonium, calcium and magnesium, chlorides, nitrates and sulfates; it must be tested for microbiological safety by the counting of mesophilic microorganisms. Ultra-pure water is the purified water submitted to additional treatment, which is generally used in laboratory test procedures. The Brazilian Pharmacopeia does not establish a requirement for testing endotoxins in purified or ultrapure water ${ }^{(17)}$. Therefore, the use of the American guide is necessary to define endotoxin standards in the water used for processing materials in the $\mathrm{SPD}^{(18)}$. It is believed that only making use of the Brazilian regulation to structure the SPD does not ensure good practices associated with the purity or absence of endotoxins in water.

The endotoxins' role in the aseptic loosening of implants is still not clear; however, researchers proved that endotoxins are at least partially responsible. Their presence increases cellular response to particles generated from the implant, and they probably interact with particle loading, implant movement, mechanical strength and floating head pressure to induce the prosthesis loosening. Studies suggest that endotoxins adhered to an implant interfere in its osseointegration, causing its loosening ${ }^{(5-19)}$.

In 2005, researchers defined three potential sources of endotoxins to patients with aseptic loosening of implants, namely: (1) before surgery, the implant may contain a significant amount of endotoxin adhered to its surface; (2) circulating endotoxin generated from gut microbiota, minor infections or dental procedures may accumulate in the particles generated from the use of the prosthesis or in the tissue around the implant; (3) subclinical bacterial biofilm. The authors affirm that microbiological studies have showed the presence of bacteria in the implant surface of patients who presented aseptic loosening, despite the absence of clinical signs of infection ${ }^{(5-19)}$.

Considering the possibility that the water used in the processing of surgical instruments might be infected by Gram-negative bacteria and might be the source of endotoxins ${ }^{(6)}$, it is important to care about the structural conditions in the SPDs, since they are units destined to the processing of health products. The effective decontamination of surgical instruments is one of the main components of quality care to ensure patient safety ${ }^{(13)}$.

Furthermore, surgical instruments processed by SPDs may become the fourth potential source of endotoxin and contribute to the loosening of orthopedic prostheses. It is important to consider the additional risk associated with the multiple use of orthopedic instruments that usually belong to the prosthesis supplier, instead of the health service. Consequently, the instruments are used by several health services, which is a factor that may contribute to the development and accumulation of bacterial biofilm on their surfaces ${ }^{(20)}$.

Considering the contamination of surgical instruments from endotoxins a complex matter, structural conditions that minimize their presence are necessary. Furthermore, the guide of the Association for the Advancement of Medical Instrumentation (AAMI) establishes four categories of water used in the reprocessing of medical devices, as well as the characteristics of each one of them, treatment methods and validation of treatment systems ${ }^{(18)}$. Surgical instruments are accessories for the installation of orthopedic prostheses and they should not represent one more risk factor.

According to the AAMI, the characteristics associated with water quality that should be analyzed are: bacteria, endotoxins, total organic carbon, $\mathrm{pH}$, hardness, dissolved solids, ionic contaminants, color and turbidity. Regarding the standard of endotoxins in purified water submitted to treatment by reverse osmosis or distillation, it must be $<10$ $\mathrm{UE} / \mathrm{ml}$. It is noteworthy that tests must be conducted when the treatment system is installed, modified or repaired. Moreover, any alteration in the characteristics of the water suggests endotoxin tests. The monitoring of bacteria level must be performed every month, and if high levels are identified, analysis of endotoxins must be conducted ${ }^{(18)}$. 
The results of the present study should be carefully regarded, considering that endotoxin tests are recommended both for devices that will be inserted and remain in the patient's body and for the rinsing water used for reprocessing critical health products. There are scientists who question the lack of regulations and requirements of good practice of biomaterials manufacture, recognizing the need to perform regular endotoxin tests, to report values of all surfaces and to give special attention in the interpretation of results, since the minimum presence of endotoxin may cause a response from the immune system ${ }^{(3,5,19,21)}$.

Although this is an innovative study, which used a methodology not yet validated, it is important to note the fact that the sensitivity to detect endotoxins was established at $0.125 \mathrm{UE} / \mathrm{mL}$.

The fact that drinking water was used to rinse surgical instruments is considered a limitation of this study. However, the regulation regarding the use of purified water to the rinsing of critical health products was published in March of 2012, with a maximum period of 24 months for the health services to implement the required adjustments.
The materials analyzed by this study were obtained in the SPD, from October to December of 2012, when the implementation project of water treatment by reverse osmosis was object of discussion at the hospital.

\section{CONCLUSION}

Presence of endotoxins in 13\% of the sterilized orthopedic surgical instruments was detected in $\geq 0.125 \mathrm{UE} /$ $\mathrm{mL}$. The processing of surgical instruments in the SPD is a complex matter that involves the validation of all stages of the process, especially when there is possibility to prevent their contamination, being necessary the adoption of regulations, and national and international guides for quality control.

It is worth mentioning the importance of establishing measures for the control of water used for processing orthopedic surgical instruments in the SPD. The results of this study suggest the difficulty of cleaning flexible bone reamers, therefore, further studies are required to analyze the impact of this finding and to recommend alternatives for the flexible reamers.

\section{RESUMO}

Objetivo: Investigar endotoxinas em instrumentais cirúrgicos esterilizados empregados em artroplastias do quadril. Método: Estudo exploratório, descritivo, desenvolvido em um hospital público de ensino. Foram selecionados seis tipos de instrumentais, a saber: raspa acetabular, raspa femural, saca-cabeça de fêmur, formão box, fresa de fêmur e cabeça de prova de fêmur. A seleção foi feita a partir da análise da dificuldade para a remoção de resíduos de sangue e osso durante a limpeza. A amostra foi constituída por 60 instrumentais cirúrgicos, que foram testados para endotoxinas em três momentos distintos. Foi utilizado o método de gel-clot pelo Limulus Amebócito Lisado (LAL) Endosafe ${ }^{\mathrm{TM}}$. Resultado: Houve formação de gel consistente com análise positiva em oito instrumentais, o que corresponde a 13,3\%, sendo quatro raspas de fêmur e quatro fresas de fêmur. Conclusão: Foram detectadas endotoxinas em quantidade $\geq 0,125$ $\mathrm{UE} / \mathrm{mL}$ em $13,3 \%$ dos instrumentais testados.

\section{DESCRITORES}

Endotoxinas; Instrumentos Cirúrgicos; Artroplastia de Quadril; Enfermagem Ortopédica; Enfermagem de Centro Cirúrgico.

\section{RESUMEN}

Objetivo: Investigar las endotoxinas en instrumentales quirúrgicos esterilizados empleados en artroplastias de la cadera. Método: Estudio exploratorio, descriptivo, desarrollado en un hospital público de enseñanza. Fueron seleccionados seis tipos de instrumentales, a saber: raspa de acetábulo, raspa femoral, sacacorchos (para extraer la cabeza femoral), gubia quirúrgica, fresa femoral y cabeza femoral de prueba. La selección se hizo desde el análisis de la dificultad para la retirada de residuos de sangre y hueso durante la limpieza. La muestra estuvo constituida de 60 instrumentales quirúrgicos, que fueron puestos a prueba para endotoxinas en tres momentos diferentes. Se utilizó el método de gelificación (Gel-clot) Lisado de Amebocitos de Limulus (LAL) Endosafe ${ }^{\mathrm{TM}}$. Resultado: Hubo formación de gel consistente con análisis positivo en ocho instrumentos, lo que corresponde a el 13,3\%, siendo cuatro raspas femorales y cuatro fresas femorales. Conclusión: Fueron detectadas endotoxinas en cantidad $\geq 0,125 \mathrm{UE} / \mathrm{mL}$ en el 13,3\% de los instrumentos probados.

\section{DESCRIPTORES}

Endotoxinas; Instrumentos Quirúrgicos; Artroplastia de Reemplazo de Cadera; Enfermería Ortopédica; Enfermería de Quirófano.

\section{REFERENCES}

1. Penedo J, Sampaio Novo S. Artroplastia total do quadril. In: Cohen M, Mattar Junior R, Jesus-Garcia Filho R. Tratado de ortopedia. São Paulo: Roca; 2007. p. 363-8.

2. Sociedade Brasileira de Quadril (SBQ). Registro Multicêntrico de Procedimentos Operatórios da SBQ: estrutura, organização e implantação [Internet]. Porto Alegre: SBQ; 2012. [citado 2014 fev. 11]. Disponível em: http://www.rempro-sbq.org.br/docs/Projeto-REMPRO.pdf

3. Revell PA. The combined role of wear particles, macrophages and lymphocytes in the loosening of total joint prostheses. J R Soc Interface [Internet]. 2008 [cited 2012 Sep 12];5(28):1263-78. Available from: http://www.ncbi.nlm.nih.gov/pmc/articles/PMC2607446/

4. Campoccia D, Montanaro L, Arciola CR. The significance of infection related to orthopedic devices and issues of antibiotic resistance. Biomaterials [Internet]. 2006 [cited 2012 Sep 12];27(11):2331-9. Available from: http://www.sciencedirect.com/science/article/pii/ S0142961205010938 
5. Greenfield EM, Bi Y, Ragab AA, Goldberg VM, Nalepka JL, Seabold JM. Does endotoxin contribute to aseptic loosening of orthopedic implants? J Biomed Mater Res B Appl Biomater. 2005;72(1):179-85.

6. U.S. Food and Drug Administration (FDA). Protecting and Promoting Your Health. Bacterial endotoxins/pyrogens [Internet]. Silver Spring: FDA; 1985 [cited 2015 May 7]. Available from: http://www.fda.gov/ICECI/Inspections/InspectionGuides/InspectionTechnicalGuides/ ucm072918.htm

7. Gorbet MB, Sefton MV. Endotoxin: the uninvited guest. Biomaterials [Internet]. 2005 [cited 2015 May 7];26(34):6811-7. Available from: http://www.sciencedirect.com/science/article/pii/S0142961205003856

8. U.S. Food and Drug Administration (FDA), Department of Health and Human Services. Guidance for industry pyrogen and endotoxins testing: questions and answers [Internet]. Silver Spring: FDA; 2012 [cited 2015 May 25]. Available from: http://www.fda.gov/downloads/ drugs/guidancecomplianceregulatoryinformation/guidances/ucm310098.pdf

9. Lipscomb IP, Sihota AK, Keevil CW. Comparative study of surgical instruments from sterile-service departments for presence of residual gram-negative endotoxin and proteinaceous deposits. J Clin Microbiol [Internet]. 2006 [cited 2015 May 7]; 44(10):3728-33. Available from: http://www.ncbi.nlm.nih.gov/pmc/articles/PMC1594772/pdf/1280-06.pdf

10. Dell RB, Holleran S, Ramakrishnan R. Sample size determination. ILAR J. 2002;43(4):207-13.

11. Brasil. Ministério da Saúde. Portaria n. 2914, de 12 de dezembro de 2011. Dispõe sobre os procedimentos de controle e de vigilância da qualidade da água para consumo humano e seu padrão de potabilidade. [Internet]. Brasília; 2011 [citado 2016 mar. 21]. Disponível em: http://bvsms.saude.gov.br/bvs/saudelegis/gm/2011/prt2914_12_12_2011.html

12. United States Pharmacopeial Convention. <85> Bacterial endotoxins test [Internet]. 2012 [cited 2015 July 13]. Available from: http://www. usp.org/sites/default/files/usp_pdf/EN/USPNF/revisions/m98830-bacterial_endotoxins_test.pdf

13. Organização Mundial da Saúde. Aliança Mundial para a Segurança do Paciente. Segundo Desafio Global para a Segurança do Paciente: cirurgias seguras salvam vidas [Internet]. Rio de Janeiro: OPA/MS; 2009 [citado 2015 jul. 13]. Disponível em: http://bvsms.saude.gov.br/ bvs/publicacoes/seguranca_paciente_cirurgia_salva_manual.pdf

14. National Health Services Estates. Comprehensive report: a review of the decontamination of surgical instruments in the NHS in England [Internet]. London, United Kingdom; 2001 [cited 2015 May 7]. Available from: http://webarchive.nationalarchives.gov.uk/20130107105354/ http://www.dh.gov.uk/assetRoot/04/12/09/13/04120913.pdf

15. Seavey R. Safe instrument reprocessing: the perioperative role. AORN J. 2015; 101(5):553-7.

16. Brasil. Ministério da Saúde; Agência Nacional de Vigilância Sanitária. Resolução da Diretoria Colegiada RDC n. 15, de 15 de março de 2012. Dispõe sobre requisitos de boas práticas para o processamento de produtos para saúde e dá outras providências [Internet]. Brasília; 2012 [citado 2015 jul. 13]. Disponível em: http://portal.anvisa.gov.br/wps/wcm/connect/7599770043e684468b198f45f4f7d4e4/ rdc0015_15_03_2012.pdf?MOD=AJPERES

17. Brasil. Ministério da Saúde; Agência Nacional de Vigilância Sanitária, Fundação Oswaldo Cruz. Farmacopeia brasileira [Internet]. Brasília: ANVISA; 2010 [citado 2015 jul. 13]. Disponível em: http://www.anvisa.gov.br/hotsite/cd_farmacopeia/pdf/volume2.pdf

18. Association for the Advancement of Medical Instrumentation (AAMI). Technical Information Report 34:2014. Water for the reprocessing of medical devices [Internet]. Arlington, VA; 2014 [cited 2015 July 12]. Available from: http://my.aami.org/store/SiteContent/previewfiles/ TIR34_1409_preview.pdf

19. Lieder R, Petersen PH, Sigurjónsson OE. Endotoxins: the invisible companion in biomaterials research. Tissue Eng Part B Rev. 2013;19(5): 391-402.

20. Zhong W, Alfa M, Zelenitsky S, Howie R. Simulation of cyclic reprocessing buildup on reused medical devices. Comp Biol Med. 2009;39(6):568-77.

21. Landgraeber S, von Knoch M, Löer F, Brankamp J, Tsokos M, Grabellus F, et al. Association between apoptosis and CD4+/CD8+ T-Lymphocyte ratio in aseptic loosening after total hip replacement. Int J Biol Sci [Internet]. 2009 [cited 2012 Sep 12];5(2):182-91. Available from: http://www.ncbi.nlm.nih.gov/pmc/articles/PMC2640493/pdf/ijbsv05p0182.pdf 